\title{
Morphological and Morphometric Study of the Development of Seminiferous Epithelium of Donkey (Equus asinus) from Birth to Maturity
}

Moustafa MNK, Sayed R, Zayed AE and Abd EI-Hafeez H.H.*

Faculty of Veterinary Medicine, Department of Anatomy and Histology, Assuit University, Egypt

\begin{abstract}
In this investigation, testes of 20 donkeys ranging from birth to maturity were studied. The postnatal morphologic and morphometric characteristics of donkey's seminiferous epithelium during the postnatal period were studied. The volume percentage of the tubular compartment (Seminiferous tubules) was about $12.76 \%$ in neonates, progressively increased with postnatal age, reaching about $78.42 \%$ of the testicular parenchyma in mature donkeys. The seminiferous tubules measured about $205 \mu \mathrm{m}$ in diameter, and their lining epithelium was about $73.7 \mu \mathrm{m}$ in height in mature animals. The supporting (Sertoli) and germ cells (gonocytes) were the main components of the seminiferous cord or (tubules). The supporting type gradually decreased in number from neonates through suckling to the premature and mature stages, while they started to acquire the morphological characteristics of mature cells in late suckling period. The gonocytes maintained the same morphological characteristics during the neonatal and suckling periods; however, they showed a slight increase in number during the latter stage. In addition, dividing germ cells were frequently observed. The germ cells were mostly demonstrated in a central position within the testicular cords of neonatal donkeys. In suckling animals, some gonocytes started to contact the basement membrane, whereas in late suckling period, most of germ cells in contact with basement membrane. In premature donkeys, the gonocytes arranged in 2-3 layers between the supporting cells. In addition, the lumination of the seminiferous cords occurred in 1.5 year. The germ cells could be distinguished to spermatogonia, and primary, as well as secondary spermatocytes. Spermatids, at different stages of transformation, were also detected within some seminiferous tubules. In adults, the semniferous cords became more coiled and were totally luminated. All kinds of germ cells could be observed within the seminiferous epithelium, representing the complete seminiferous cycle and spermatogenesis is completed by 2 years of age. The present study provides baseline information for further experiment or quantitative studies exploring normal development of the testis and hormonal regulation of Sertoli cells, spermatogonial stem cells and spermatogenesis in donkey and other related species.
\end{abstract}

Keywords: Development; Donkey; Testis; Semniferous cycle; Interstitial tissue; Morphology

\section{Introduction}

The testis is the important organ within the male reproductive system. The testis is a bipartite glandular organ, with both exocrine and endocrine components. Its exocrine function is to produce male germ cells; meanwhile, its endocrine role is mainly directed to produce male sex hormone [1,2]. The knowledge of testicular development in mammals is of a great importance for understanding congenital malformation and their teratologic origin. The histomorphological features of the testis, at various stages of growth and development, have been described in several species [3] in ram; [4] and 1 [5] in bull; [6] in camel; [7] in goat; [8] in pig; [9] and [10] in cat [11] in dog; [12]; [13] in opossum; [14] in marsupial; [15]; in sika deer; [16] in beef bulls and [17] in wild cat. These authors ascertained that the sex cords of the testis are composed of two cell types; primordial cells and supporting types. The point of controversy is the fate of these two cell types in the postnatal period of development. Although, Saber [18] and Nipken and Wrobel [19] studied the age related changes in the adult testis of donkey aging from 1.5 to 10 years and Neves et al., [20] studied the comparative testis morphometry and seminiferous epithelium cycle length in donkeys and mules, information about the postnatal period of the donkey testis (from birth until puberty) is lacking in the available literature. The present investigation was undertaken to highlight the histomorphological changes, as well as to indicate some morphometric parameters, concerned with the seminiferous epithelium of donkey's testis during the postnatal life. In the present study, therefore, we intended to categorize the seminiferous epithelial stages in the donkey testis. Information about the stages of seminferous cycle is essential for morphological and functional researches on the testes and provides the basis of understanding testicular regulatory mechanisms [15]. Testicular biometric parameters are very important for establishing reproductive patterns and, consequently, the development of protocols for assisted reproduction in different species [21].

The present investigation was carried out on 20 testes from 20 healthy donkeys (Equus asinus) representing different stages of postnatal life viz., newly born; early and late sucklings, as well as premature and mature animals (Table 1).

Ages of animals were determined by correlating the appearance of specific dental features [22]. Donkeys also have six top and six bottom front teeth. Ageing by growth of new front teeth is similar to horses. New adult incisors appear at 21/2,31/2 and $41 / 2$ years old.

The left testis and the adjoining spermatic cord were obtained by castration in the Department of Anatomy and Histology, Faculty of

*Corresponding author: Abd El-Hafeez HHA, Faculty of Veterinary Medicine Department of Anatomy and Histology, Assuit University, 51726, Egypt, Tel: 00210668628; E-mail: hhmmzz91@gmail.com

Received June 24, 2015; Accepted September 01, 2015; Published September 03, 2015 .

Citation: Moustafa MNK, Sayed R, Zayed AE, Abd El -Hafeez (2015) Morphological and Morphometric Study of the Development of Seminiferous Epithelium of Donkey (Equus asinus) from Birth to Maturity. J Cytol Histol 6: 370. doi:10.4172/21577099.1000370

Copyright: @ 2015 Moustafa MNK, et al. This is an open-access article distributed under the terms of the Creative Commons Attribution License, which permits unrestricted use, distribution, and reproduction in any medium, provided the original author and source are credited. 


\begin{tabular}{|l|c|c|c|c|c|c|}
\hline Age of animals & $\begin{array}{c}\text { No. of } \\
\text { animals }\end{array}$ & $\begin{array}{c}\mathbf{W}_{\mathbf{T}} \\
\mathbf{( g )}\end{array}$ & $\begin{array}{c}\mathbf{V}_{\mathbf{T}} \\
\left(\mathbf{c m}^{3}\right)\end{array}$ & $\begin{array}{c}\mathbf{V}_{\mathrm{p}} \\
\left(\mathbf{c m}^{3}\right)\end{array}$ & $\begin{array}{c}\mathbf{V}_{\mathrm{Tu}} \\
\left(\mathbf{c m}^{3} \mathbf{)}\right.\end{array}$ & $\begin{array}{c}\mathbf{V}_{\mathbf{1 T}} \\
\left(\mathbf{c m}^{3}\right)\end{array}$ \\
\hline $\begin{array}{l}\text { Neonatal animals } \mathbf{( 5} \\
\text { days) }\end{array}$ & 3 & $5.5 \pm 0.3$ & $5.0 \pm 0.2$ & 4.45 & 0.57 & 3.88 \\
\hline $\begin{array}{l}\text { Early suckling } \\
\text { animals (2 months) }\end{array}$ & 4 & $6.5 \pm 0.4$ & $6.0 \pm 0.3$ & 5.34 & 1.74 & 3.60 \\
\hline $\begin{array}{l}\text { Late suckling } \\
\text { animals (6 and 9 } \\
\text { months) }\end{array}$ & 4 & $6.9 \pm 0.6$ & $6.5 \pm 0.2$ & 5.79 & 2.44 & 3.35 \\
\hline $\begin{array}{l}\text { Premature animals } \\
\text { (1.5 years) }\end{array}$ & 4 & $40.0 \pm 3.6$ & $45.0 \pm 3.1$ & 40.05 & 31.23 & 8.82 \\
\hline $\begin{array}{l}\text { Mature animals (2-3 } \\
\text { years) }\end{array}$ & 5 & $95.5 \pm 8.5$ & $100.0 \pm 6.2$ & 89.00 & 69.80 & 19.20 \\
\hline
\end{tabular}

Values of testicular weight and volume are represented by means \pm standard deviation (SD).

Abbreviations: $\mathrm{W}_{\mathrm{T}}$, testicular weight; $\mathrm{V}_{\mathrm{T}}$, testicular volume; $\mathrm{Vp}$ parenchymal volume; $\mathrm{V}_{\mathrm{T}}$, tubular volume; $\mathrm{V}_{1 \mathrm{~T}}$, volume of interstitial testicular tissue.

Table 1: Quantitative analysis of postnatal testicular development in donkeys.

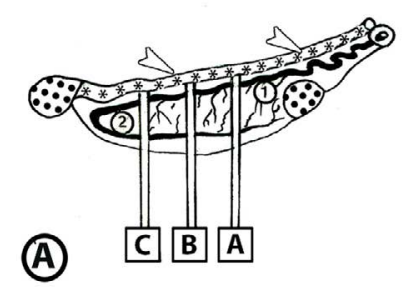

(B)

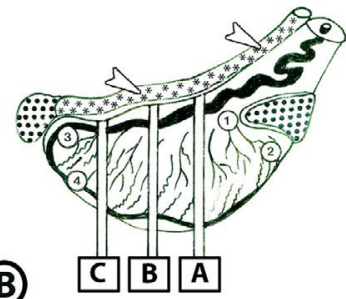

Figure 1: small blocks $(1 \times 1 \times 1 / 2 \mathrm{~cm})$ taken from the different regions of the testis after perfusion.

A: Diagrammatic representation of tissue sampling from left testis in neonatal and suckling animals. Five tissue blocks are collected from different regions of testis; head extremity (1), tail extremity (2), and three complete transverse sections $(A, B, C)$ mid-way between the head and tail extremities.

$B$ : Diagrammatic representation of tissue sampling from left testis of premature and mature animals. Nineteen tissue blocks are collected from different areas of the head extremity $(1,2)$, tail extremity $(3,4)$ and three transverse sections $(A, B, C)$. Slice $B$ is taken from the testicular equator; sections $A$ and $C$ are equidistant from the equator and cranial or caudal pole, respectively. From each of the three slices five tissue blocks are obtained from the center, medial, lateral, epididymal and free sides.

- = Epididymis,${ }^{*}$, arrowhead $=$ Ductus deferens

Values of testicular weight and volume are represented by means \pm standard deviation (SD).

Abbreviations: WT, testicular weight; VT, testicular volume; Vp, parenchymal volume; VTu, tubular volume; VI T, volume of interstitial testicular tissue.

Veterinary Medicine, Assiut University, Egypt. The testis was dissected way from the attached structure. The testes were weighted in $g$ and their volume was determined in $\mathrm{cm}^{3}$ by fluid displacement, using a cylinder half-filled with normal saline and the volume displaced by the testis was recorded (The Archimedes principle) [23].

The testes were slowly perfused through the testicular artery using small amount of neutral buffered formalin or Bouin's fluid to avoid expansion of testicular vessels. After perfusion, small blocks $\left(1 \times 1 \times \frac{1}{2}\right.$ $\mathrm{cm}$ ) were taken from the different regions of the testis (Figure 1).

Thereafter, the samples were immersed in a special fixative [24] for 24 hours. The fixative used is composed of the below mentioned (Table 2):

The specimens were dehydrated in ascending grades of ethanol, cleared in methyl benzoate and embedded in paraffin. Five to seven $\mu \mathrm{m}$ thick sections were cut and stained with Haematoxylin and Eosin, Crossman's trichrome stains [25].

\section{Semi thin section}

Tissue blocks $(2 \times 2 \times 2 \mathrm{~mm})$ form the previously fixed material were washed in $0.1 \mathrm{M}$ phosphate buffer ( $\mathrm{pH} 7.4$ ), post fixed in $1 \%$ buffered Osmium tetra oxide and washed in the same buffer. After dehydration in graded ethanol, the samples were embedded in EponAraldite mixture [26]. Semi thin sections covering the different regions of testis $(1 \mu \mathrm{m}$ thick) were cut and stained with toluidine blue.

\section{Morphometric Studies}

The morphometric measurements were carried out using an image analysis system (Leica Q500MC).

The parameters such as, the number, the size and the place of measurement frame or crossed measurement points were adjusted by the observer according to the region of interest. The program also provided the function of distance measurement, including transforming the pixels pitch to the real distance automatically by input of the coefficient. After the measurement, the program could save the altered images and output the measurement results to ".csv" files which could be opened by spreadsheet software such as Microsoft Excel for further analysis [27].

\section{The measurements included the following parameters}

Volume percentage and absolute volume of the seminiferous cords (or tubules) together with the interstitial tissue, the tubular (or cord) diameter and the height of seminiferous epithelium.

\section{For calculation of the parenchymal volume}

The parenchymal volume was determined by subtraction of $11 \%$ from the testicular volume. These $11 \%$ represents the volume of the tunica albuginea and mediastinum testis [28].

\section{For calculation of volume percentages and total volume of the seminiferous tubule and intertubular space}

The volume percentage of seminiferous cords and/or tubules and interstitial tissue were determined. The absolute volume of cords (tubular compartment) and the interstitial tissue compartment per testis were calculated by knowledge of parenchymal volume and the volume percentages of the cords and/or tubules and interstitial tissue.

\section{Steps for calculation of volume percentage}

Volume percentage of the cords or tubules and that of the interstitial tissue per each testis were calculated as following:

The size and the place of measurement frames were adjusted by the observer according to the region of interest. After that they recorded this area of measurements representing $\mathrm{X}$.

1- The volume density of seminiferous tubules to the whole testicular tissue means the ratio of "seminiferous Surface tubule/reference area [29]. For determining the volume density:

D The intersections overlying the seminiferous tubule were counted in selected determined fixed area of 15 random histological felid from different 3 animals of each age group. Using a hand-held mouse, the cursor traced around the boundary of the interest tubule or interubular area. The

\begin{tabular}{|l|l|c|}
\hline & $\begin{array}{l}\text { Parafomaldehyde, 25\% freshly } \\
\text { prepared }\end{array}$ & $\mathbf{4 0 ~} \mathrm{ml}$ \\
\hline \multirow{4}{*}{ Wrobel-Moustafa-Fixative } & Phosphate buffer (0.2 M, pH 7.4) & $125 \mathrm{ml}$ \\
\hline & Saturated picric acid & $37.5 \mathrm{ml}$ \\
\hline & Calcium chloride & $5.0 \mathrm{mg}$ \\
\hline & Glutaraldehyde 25\% & $1.25 \mathrm{ml}$ \\
\hline & Add distilled water up to & $250 \mathrm{ml}$ \\
\hline
\end{tabular}

Table 2: Components of the fixative 
Citation: Moustafa MNK, Sayed R, Zayed AE, Abd El -Hafeez (2015) Morphological and Morphometric Study of the Development of Seminiferous Epithelium of Donkey (Equus asinus) from Birth to Maturity. J Cytol Histol 6: 370. doi:10.4172/2157-7099.1000370

software calculated the pixel dimension enclosed within the traced area. Then the pixel dimension was multiplied by the coefficient of pixels pitch and the real distance to obtain the area of the tubule [30,31].

After recorded the mean of the total area occupied by seminiferous tubules. The area of the interstitium was determined by subtracting the seminiferous tubule area from the total section area $[29,30]$.

After calculation of this ratio representing the volume densities of seminiferous tublues and interstitial tissue using this ratio to give the percentage of volume denstities by multiplied this ratio by 100 [32].

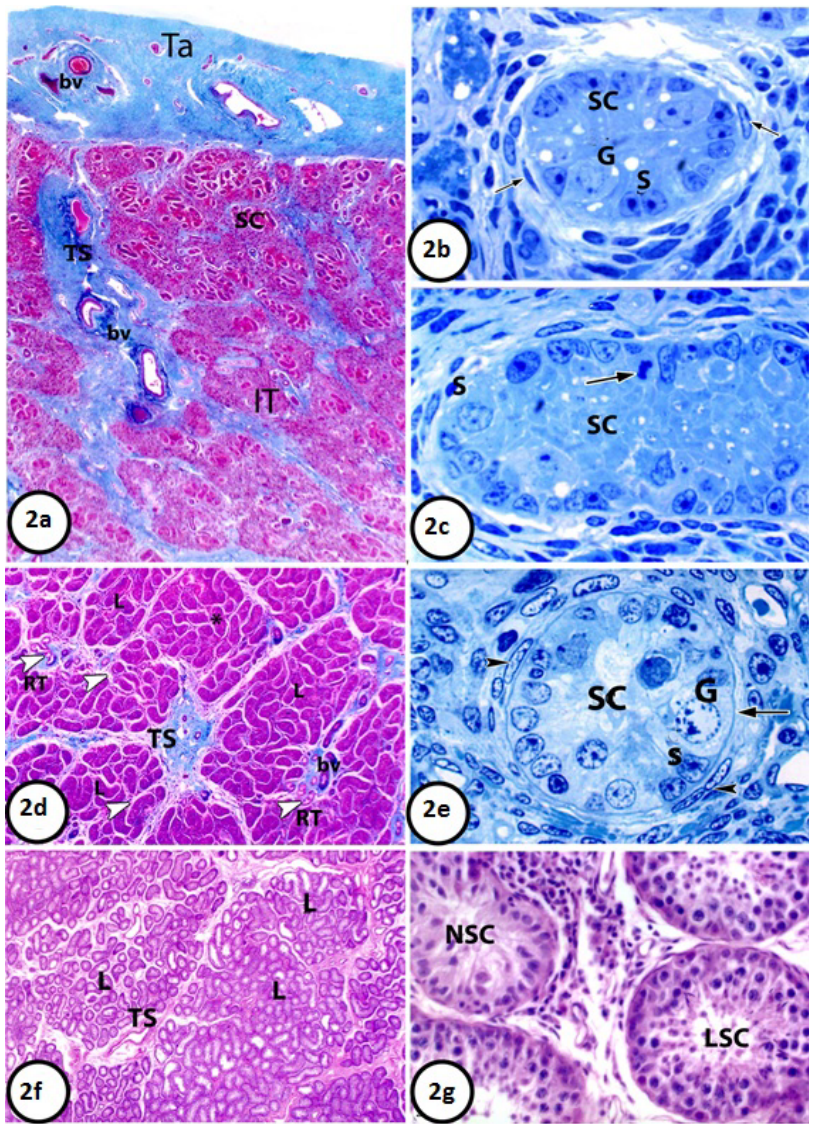

Figure 2: 2A: Paraffin section in the of testis of newly born donkey showing tunica albuginea (Ta), testicular septum (Ts), semniferous cords (SC), interstitial tissue (IT) and blood vessels(bv). (Crossmon's Trichrome, 25X). 2B: Semithin section in the testis of newly born donkey showing one seminiferous cord (SC) surrounded by one discontinuous layer of flattened cells (arrows), gonocytes (G) supporting cells (S). Notice the presence of variable- sized vacuoles within the germ and supporting cells. (Toluidine blue, 1000X). 2C: Semithin section in the testis of newly born donkey showing one seminiferouscord (SC). Notice, mitosis in gonocytes (arrow) (Toluidine blue, 1000X). 2D: Paraffin section in testis of suckling donkey (2 months old) was showing numerous irregularly distributed testicular lobules $(\mathrm{L})$. Each lobule consists of tortuous seminiferous cords $\left({ }^{*}\right)$ and narrow interstitial tissue (arrow heads) in-between. Notice that the testicular septa (TS) are thick in the areas hosting testicular vessels (bv) and rete testis tubule (RT, arrow head). (Crossmon's Trichrome, 50X). 2E: Semithin section in the testis of suckling donkey (6 months old) showing one semniferous cord (SC), gonocytes (G), supporting cells with indented nuclei (S) and peritubular cells (arrow head). Notice most of germ cells appear contacting the basement membrane (arrow). (Toluidineblue 1000X). 2F: Paraffin section in premature donkey testis (1.5 year) showing large number of irregular lobules $(L)$ separated by irregular testicular septa (TS). The semniferous cords have increased both in length and convolutions. Notice some semniferous tubules show the primary signs of lumination are present besides the non-luminated and luminated ones. (Haematoxylin and Eosin, 50X). 2G: Paraffin section in premature donkey testis (1.5 year) showing non luminated semniferous cords (NSC) and luminated seminiferous cords (LSC). (HaematoxylinandEosin 400X).
2- we using the volume percentage of the seminiferous tubule and intertubular space for calculation of the total volume of these testicular components $[21,33]$. The volume of the seminiferous epithelium was obtained by multiplying its percentage within the seminiferous tubule by the parenchymal volume, dividing the result by 100 [33].

\section{The measurements were summarized as following}

The parenchymal volume $(\mathrm{Vp})=$ testicular volume $-11 \%$

Fixed total area of meauserment $=\mathrm{X}$

$\mathrm{VTu},($ tubular volume $) \%=($ area of seminiferous tubules $\times 100) / \mathrm{X}$

Area of interstitial tissue $=\mathrm{X}$ - area of seminiferous tubules

VIT, (volume of interstitial testicular tissue $) \%=($ area interstitial tissue $\times 100) / \mathrm{X}$

Total Volume of the cords or tubules $\mathrm{VTu}=\% \mathrm{VTu}$ multiplied by Vp Divided by 100

Total Volume of the interstitial tissue VI T $=\%$ VI T multiplied by Vp Divided by 100

Abbreviations: Vp: parenchymal volume; VTu: tubular volume; VIT: volume of interstitial testicular tissue

\section{The tubular (or cord) diameter}

Cross and longitudinal sections of the cords were used to measure their diameter in newly born and suckling animals as well as the tubular diameter and epithelial height in premature and mature ones. The selected cross- sections of the round-shaped seminiferous tubule containing a clear lumen were used to measure their diameter. The mean diameter of the seminiferous tubules was estimated by measuring 20 tubule cross sections, made as circular as possible, of each animal We measured the height of the seminiferous epithelium, from the basal membrane to the luminal edge. The diameter results were expressed mean \pm standard deviation (SD) [21,27].

\section{Counting of Sertoli cells and spermatognic cells}

Most studies quantifying cell abundances in the testis have been performed by profile- Counting in semi-thin sections [34].

\section{Stages of seminferous epithelial cycle}

The stages of the seminiferous epithelium cycle were characterized using the tubular morphology method; the seminiferous epithelial cycle was classified based on variations in shape and localization of spermatogenic cells in round seminiferous tubules [35]. Each cellular association, were consisting of one or two generations of spermatogonia, spermatocytes and spermatids [36].

\section{Results}

\section{Neonatal animals}

The testicular parenchyma of newly born donkeys was lobulated into irregular lobules via numerous irregular septa. Each lobule composed of variable islets of solid seminiferous cords that surrounded by a massive interstitial tissue (Figure 2a). The seminiferous cords constituted about $12.76 \%$ of the testicular parenchyma (Table 3 and Figure 3). The seminiferous cords were $(43.70 \mu \mathrm{m})$ in diameter (Table 4). They were forming of two types of cells; supporting and germ type. The supporting (Sertoli) cells (about 15 cells per cord cross section) were columnar in shape and radially arranged on a less defined basal lamina (Figure $2 b$ ). They had more or less defined outlines giving the 


\begin{tabular}{|l|c|c|}
\hline Age of animals & $\begin{array}{c}\text { Seminiferous cords } \\
\text { and / or tubules }\end{array}$ & $\begin{array}{c}\text { Interstitial } \\
\text { Tissue }\end{array}$ \\
\hline Neonatal animals (5 days) & $12.76 \pm 1.6$ & $87.24 \pm 1.6$ \\
\hline Early suckling animals (2 months) & $32.68 \pm 3.0$ & $67.31 \pm 2.2$ \\
\hline $\begin{array}{l}\text { Late suckling animals (6 and 9 } \\
\text { months) }\end{array}$ & $42.25 \pm 4.4$ & $57.75 \pm 4.4$ \\
\hline Premature animals (1.5 years) & $77.97 \pm 1.8$ & $23.65 \pm 3.1$ \\
\hline Mature animals (2-3 years) & $78.42 \pm 0.5$ & $21.56 \pm 0.5$ \\
\hline
\end{tabular}

Values are represented by means \pm standard deviation (SD)

Table 3: Volume percentages of seminiferous cords and / or tubules and interstitial tissue in the postnatal testes of donkeys.

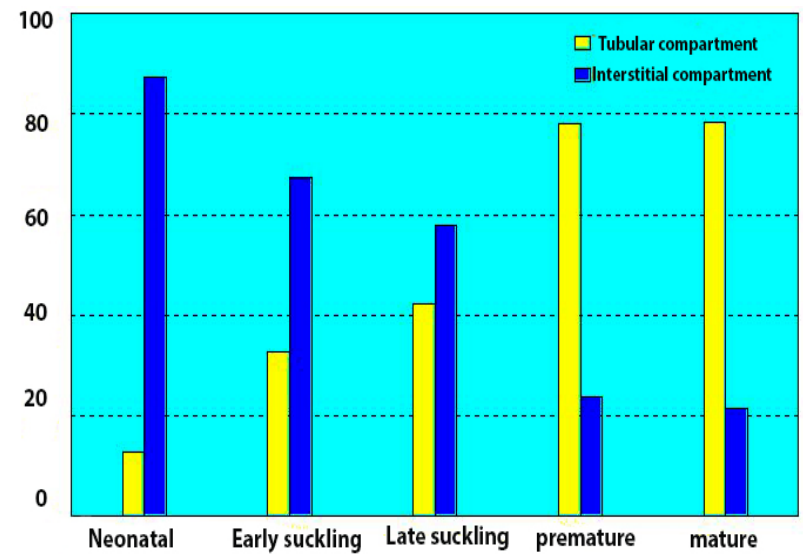

Figure 3: Volume percentages of both tubular and interstitial compartments in the testis during different postnatal ages.

\begin{tabular}{|l|c|c|}
\hline Age & Epithelial height $(\boldsymbol{\mu m})$ & Tubular diameter $(\boldsymbol{\mu m})$ \\
\hline Neonatal animals (5 days) & - & $43.70 \pm 2.18$ \\
\hline $\begin{array}{l}\text { Early suckling animals (2 } \\
\text { months) }\end{array}$ & - & $55.46 \pm 2.07$ \\
\hline $\begin{array}{l}\text { Late suckling animals(6 and } \\
\text { 9 months) }\end{array}$ & - & $60.16 \pm 3.84$ \\
\hline $\begin{array}{l}\text { Premature animals (1.5 } \\
\text { years) }\end{array}$ & $60 \pm 1.24$ & $143.57 \pm 9.96$ \\
\hline Mature animals (2-3 years) & $72.7 \pm 1.98$ & $205.6 \pm 6.65$ \\
\hline
\end{tabular}

Values are represented by means \pm standard deviation (SD). $(-)=$ Not estimated Table 4: Epithelial height and diameter of seminiferous cords and / or tubules in the postnatal testes of donkeys.

bulk of the seminiferous cords a segmented appearance. Their nuclei were vesicular, irregularly outlined and had large deeply stained nucleoli together with small chromatin aggregations. The cellular cytoplasm was moderately staining and containing various-sized supranuclear vacuoles (Figure 2b). The germ cells (gonocytes) were few in number (2-3 per cord cross section) and randomly distributed in the bulk of the seminiferous cords. Some cells were locating in a more or less central position; others were peripherally located and sometimes contacted the basal lamina (Figure $2 \mathrm{~b})$. They had large vesicular nuclei $(7 \mu \mathrm{m}$ in diameter) with one or two nucleoli. Their cytoplasm was lightly staining and contained small to medium-sized vacuoles. Mitotic figures were frequently observing in germ cells (Figure 2c). Some disintegrating cells at different stages of degeneration (ranging from pyknosis to complete disintegration) were also demonstrated in the seminiferous cords. A discontinuous layer of spindle-shaped cells with elongated oval nuclei was observed surrounding the seminiferous cords, representing the differentiating myoid cells (Figure $2 b$ ).

\section{Suckling animals}

In suckling animals, the arrangement of testicular lobules was also irregular and not showing any particular pattern. Each lobule was consisted of several seminiferous cords which surrounded by relatively narrow interstitial spaces when compared with that in newly born animals (Figure 2d). The seminiferous cords were constituted about $32.86 \%$ of the testicular parenchyma (Table 3 and Figure 3 ).

The seminiferous cords showed the same morphological features as that of newly born animals, which consisted of supporting and germ cells. The supporting cells showed a slight decrease in number (about 11 per cord cross section) when comparing with the pervious age (Figure 2e). They had irregular oval nuclei containing deeply staining nucleoli and many chromatin aggregates. Some nuclei appeared indented, taking more or less similar form as that of mature cells.

The gonocytes relatively increased in number (3-6 per cord cross section) than that of newly born animals (Figure 2e). They were oval or spherical in shape with lightly stained cytoplasm and appeared at different positions in the bulk of seminiferous cords. Some cells were central and others locating either near or contacting the basement membrane. The latter cells progressively increased in number with advancement of age (Figure 2e), where most of them appeared in contact with the basement membrane in the late suckling period (6 and 9 months of age). The nuclei of germ cells were spherical and vesicular, which had few small chromatin aggregations that form fine network attaching to the nuclear membrane. Occasional disintegrating germ cells (with shrunken cytoplasm and pyknotic nuclei) were also demonstrated (Figure 2e). The basal lamina of seminiferous cords appeared more developed than that in newly born animals. In 6 and 9 months old animals, the basement membrane became more distinctly recognizing. The peritubular cells formed a more or less continuous layer around the seminiferous cords. With advancement of age, a second discontinuous layer could be demonstrated around some seminiferous cords (Figure 2e). The seminiferous cords constituted about $42.25 \%$ of the testicular parenchyma (Table 3 and Figure 3). The diameter of seminiferous cords was about $55.46 \mu \mathrm{m}$ at early suckling animals and became $60.16 \mu \mathrm{m}$ at late suckling animals (Table 4).

\section{Premature animals}

The testicular parenchyma consisted of large number of irregular lobules separated by septa of variable thickness (Figure 2f). Such irregular arrangement of the lobules and septa remained a peculiar picture of the testis. The seminiferous cords were increased in both in length and convolution on the expense of the interstitial tissue. Volume percentages of the seminiferous cords showed a double-fold increment than that of suckling animals. The seminiferous cords constituted about $77.97 \%$ of the testicular parenchyma (Table 3 and Figure 3).

The seminiferous cords displayed different pictures of maturation, of which some lobules showed luminated seminiferous cords and others were non-luminated. In some lobules, however, the luminated and nonluminated cords partaked the picture (Figure 2g). Most of the nonluminated cords showed several variable sized vacuoles that coalesced to form central spaces (primary signs of lumination). In these cords, the supporting cells were relatively decreased in number than in suckling animals. Most of them acquired a picture similar to that of the mature cells, which showing indented nuclei and lightly stained nucleoplasm. The germ cells; however, increased in number than that in the previous stage. Some of them appeared contacting the basement membrane and showed the characteristic features of spermatogenic cells; others had the features of primary and secondary spermatocytes, but had no contact with the basement membrane (Figure 4a). The luminated seminiferous cords (seminiferous tubules) were larger in 
Citation: Moustafa MNK, Sayed R, Zayed AE, Abd El -Hafeez (2015) Morphological and Morphometric Study of the Development of Seminiferous Epithelium of Donkey (Equus asinus) from Birth to Maturity. J Cytol Histol 6: 370. doi:10.4172/2157-7099.1000370

diameter (about $144 \mu \mathrm{m})$ (Table 4) than that of non-luminated ones. The seminiferous epithelium was about $60 \mu \mathrm{m}$ (Table 4) in height and formed of supporting and germ cells (Figure $4 \mathrm{~b}$ ). The supporting type was exhibiting inconspicuous cell boundaries and was radially arranged in between collections of germ cells. Their nuclei were lightly staining, mostly indented and had distinct nucleoli, and located at variable distances from the basement membrane. Different germ cells were demonstrated in the seminiferous tubules. Spermatogonia were irregular or oval and showing variable contact with the basement membrane. Their nuclei were large, oval-shaped and showing inconstant nucleoli together with coarse chromatin particles. Primary spermatocytes were the second layer of germ cells; they had no contact with the basement membrane. They were oval or rounded and possessing rounded centrally located nuclei with coarse chromatin aggregations and less defined nuclear membrane. The secondary spermatocytes were demonstrating only in some tubules and were smaller than the primary ones. Their nuclei were also smaller than those of primary spermatocytes, but had distinct nuclear membrane and few chromatin particles. Spermatids at different stages of transformation were observed in some seminiferous tubules (Figure $4 \mathrm{~b}$ )

\section{Mature animals}

The irregular lobular arrangement which was described in the previous stages remained a characteristic feature. The testicular lobules consisted of numerous, highly tortuous seminiferous tubules and narrow interstitial spaces in between. The seminiferous tubules measured $205 \mu \mathrm{m}$ in diameter (Table 4), and constituted about $78.42 \%$ of the testicular parenchyma, and their lining epithelium was about $73.7 \mu \mathrm{m}$ (Table 4) in height.

In all mature animals, the seminiferous epithelium displayed active spermatogenesis, where eight (I-VIII) stages (cellular associations) of the spermatogenic cycle were demonstrated in different sections of the seminiferous tubules (Figure 5). Each of these associations from of certain collection of germ cells in-between the radially arranged

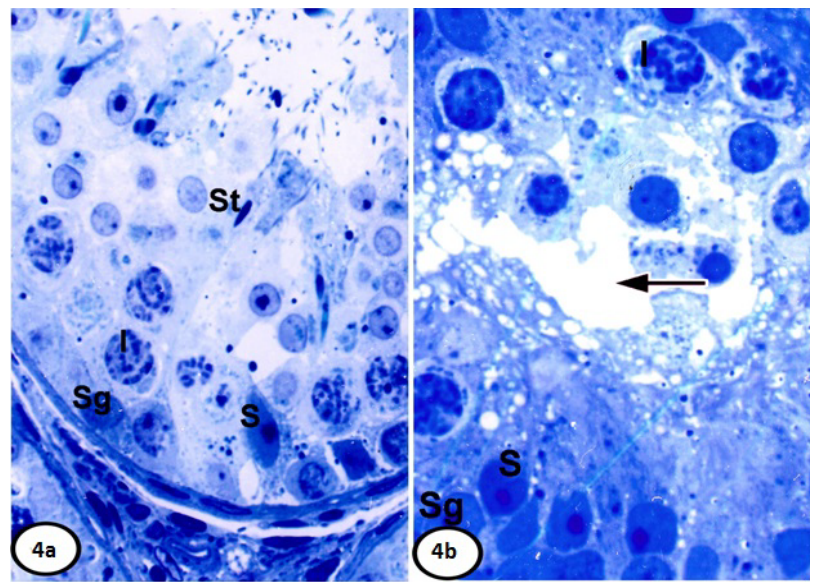

Figure 4: Semithin section in premature donkey testis (1.5 year). (Toluidine blue, 1000X). 4a: Semithin section in premature donkey testis (1.5 year) showing luminated semniferous cord. The semniferous epithelium is composed of Sertoli cells (S) and germ cell appears in different steps of differentiation from spermatogonia $(\mathrm{Sg})$, primary spermatocytes $(\mathrm{I})$, to spermatids (St). 4b: Semithin section in premature donkey testis (1.5 year) showing seminiferous cords at early stages of lumination. Supporting cells (S) are arranged radially on the basement membrane. Some germ cells show features of spermatogenic cells, primary spermatocytes (I), Notice the signs of lumination in the center of the cord.

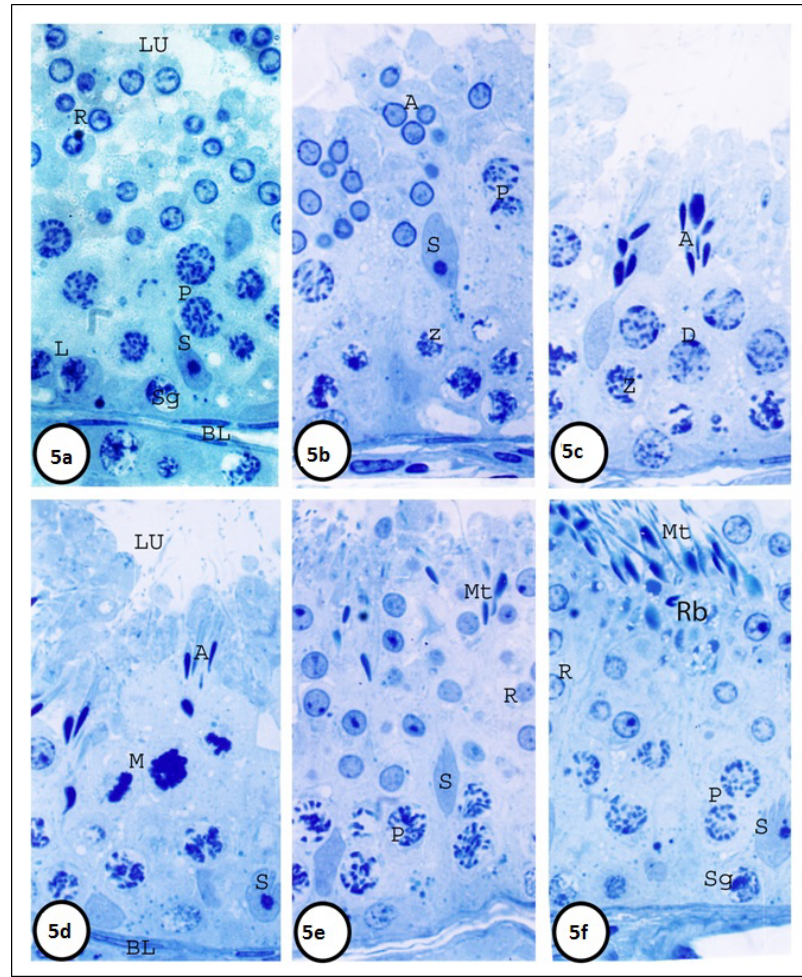

Figure 5: 5a: Stage I: is characterized by two generations of primary spermatocytes (leptotene and pachytene) and one generation of cap-phase round spermatids $\mathbf{5 b}$ : Stage II: is characterized by the leptotene primary spermatocytes were changing to zygotene, and one generation of acrosomal -phase round spermatids. 9c: Stage III: Pachytenes entered the diplotene stage that had larger nuclei (Figure 5c). Spermatids nuclei became more elongated and condensed (acrosomal phase) and arranged in bundles. . In the basal compartment, zygotene spc are additionally seen. 9d: In Stage IV: The most prominent feature of this stage was presence of second meiotic division (M) and secondary spermatocytes (Spll). Zygotene spc (Z) are also identified. 5e: In Stage V-VII, the seminiferous epithelium was composing of two generations of spermatids are observed; elongated and round While only one generation of spc (pachytene, p) is basally located. $\mathbf{5 f}$ : In Stage VIII, the maturation phase spermatids on the free border of the seminiferous epithelium .Residual bodies were also demonstrating in this stage and pachytene is basally located. 5a-5f: Semithin sections in the testis of mature donkey (2 years old) showing six cellular associations representing stages I, II, III, IV, V-VII and VIII of the semniferous epithelial cycle, respectively. (Toluidine blue, 1000X).

Abbreviations: S (Sertoli cells), Sg (spermatogonia), L (leptotene primary spermatocytes), Z (zygotene primary spermatocytes), P (pachytene primary spermatocytes), D (diplotene primary spermatocytes), $R$ (round spermatids), A (acrosomal phase spermatides), Mt (mature spermatids), M (meiosis), BL (basal lamina of seminiferous tubules), Lu (lumen of seminiferous tubules, $\mathrm{Rb}$ (residual body).

Sertoli cells. The latter cells had irregular oval and vesicular nuclei with prominent nucleoli and several indentations (Figure 5).

Stage I: The cellular association in this stage included spermatogonia on the basement membrane, two generations of primary spermatocytes (leptotene and pachytene) and one generation of cap-phase round spermatids (Figure 5a). The spermatogonia showed variable contact with the basement membrane, had oval or rounded nuclei that with many small chromatin particles. The leptotene primary spermatocytes represented the second layer of germ cells; they had no contact with the basement membrane. Their nuclei had fine chromatin threads. The pachytene primary spermatocytes formed the third layer of the germ cells; their nuclei had coarse chromatin particles and inconspicuous nuclear membrane. The cap-phase round spermatids formed the 
innermost layer of germ cells facing the tubular lumen. They had rounded nuclei, which was partially covered by a deeply stained acrosomal cap.

Stage II: It differed from the previous stage in the following: The leptotene primary spermatocytes changed to zygotene, which was characterized by partial displacement of the chromatin contents of their nuclei. The cap-phase spermatids started elongation and condensation of their nuclei; the entire nucleus was covered by acrosomal cap (Figure 5b). Stage III: Pachytenes entered the diplotene stage that had larger nuclei (Figure 5c). Spermatids nuclei became more elongated and condensed (acrosomal phase).

Stage IV: The most prominent feature of this stage was the meiotic figures in the old primary spermatocytes. Secondary spermatocytes (the results of the first meiotic division) were also demonstrated in this stage, these cells were nearly half the size of the primary spermatocytes, their nuclei showed few chromatin aggregations and clear nuclear membrane. The nuclei of late acrosomal phase spermatids were more elongated and condensed; they appeared implanted at deeper positions in the Sertoli cells (Figure 5d).

Stage V - VII: These three stages had nearly the same composition of their cellular associations. In addition to the Sertoli cells, the seminiferous epithelium composed of young pachytene primary spermatocytes and two generation of spermatids. The young generation of spermatids (Golgi phase) were resulted from the second meiosis seen in stage IV; they appeared round with small rounded nuclei. The old generation of the latter cells (maturation phase) resulted from the second maturation division were observing in stage IV; it attacheded to the Sertoli cells at variable distance from the lumen (Figure 5e).

Stage VIII: This stage differed from the previous one in the presence of the maturation phase spermatids on the free border of the seminiferous epithelium (Figure 5f). Residual bodies were also demonstrated in the juxta-luminal part of the Sertoli cell cytoplasm.

\section{Discussion}

The present study emphasized an irregular arrangement of the testicular lobules of the donkey during various stages of the postnatal life. Such arrangement does not allow some lobules to have direct contact with the mediastinum testis.

The tubular compartment of donkey's testis showed an increase in volume percentage at the expense of the interstitial tissue during the postnatal age due to increased tubular convolutions. This variant was about $13 \%$ in neonates, which progressively increased with age reaching about $78 \%$ in mature donkeys. Authors in this study, Nipken et al., [19] recorded the same volume percentage of the seminiferous tubules during sexual maturity in the same animals' species. A similar age related increase of tubular convolutions associated with a decreased intertubular space was demonstrated also in Assam goat [7], in beagle dogs [37], in indigenous bull (Bos indicus) [38].

The present study revealed that the supporting and germ cells were the main cellular constituents of the seminiferous cords (tubules) in all postnatal stages. The supporting type gradually decreased in number from neonatal through suckling to the premature and mature stages. This finding has been reported in human being from newborn to adult stage [38] and in bovine [39,40] and even during the progressive stage (1.5-5 years of age) of sexually matured donkey [19]. Since mitotic figures in supporting cells could not be observed during postnatal development, their decrease in number could be attributed to the progressive increase in the testicular volume as well as the length and width of seminiferous tubules [39]. Unlikely, authors in this study [41] considered that the increase in the bovine tubular size during the first 20 weeks was due to the proliferation of both presumptive Sertoli and germ cells a difference which may be species specific.

The supporting cells started to acquire their mature morphological characteristics in the late suckling period ( 9 months of age). In the same respect, authors in this study [19] mentioned that the formation of the tubular lumen during puberty in donkey is concomitant with the morphological differentiation of supporting cells into typical Sertoli cells. However, authors in this study [42] recorded an earlier appearance of Sertoli cells in Holstein bulls (5-6 months of age). In rat, it was suggested that Sertoli cell differentiation is relted to increasing the circulating gonadotrophins during childhood [43]. In this investigation, the germ cells had the same morphological characters during the neonatal and suckling periods of postnatal life; however, they showed a slight increase in number during the latter stage. They were represented by 2-3 cells per cord cross section in the seminiferous cords of neonatal animals that increased to 3-6 cells in suckling ones. In addition, dividing germ cells were occasionally seen during postnatal development. Many authors in these studies [44,45] in bull, $[5,46]$ in dogs, [47] in ovine have recorded division of the developing postnatal germ cells. It can be postulated that this division is a necessary phenomenon for renewal of such cells. Concerning the location of germ cells in the seminiferous cords, they were mostly demonstrated occupying a central position in neonatal animals. In suckling animals, some of them started to contact the basement membrane. In the late suckling period, most germ cells were seen contacting the basement membrane. In agreement with study [5], movement of the developing germ cells from central to peripheral positions in the seminiferous cords was coincident with an increase in tubular diameter. It can be presumed that the movement of germ cells toward the tubular basal lamina creates a distance on this membrane with a subsequent increase in the external tubular diameter. In agreement with many studies in different species in investigation [4,5] in bulls and in the study [46] in dogs degenerating germ cells were sometimes seen during postnatal development. Degeneration or death of some germ cells seems to be a result of two reasons. First, the dying germ cells are those cells that fail to contact the basement membrane [47]. Second, the seminiferous cords show only a slight increase in their diameter during development that may not be enough to supply space for the newly added germ cells from the division processes. However, a small number of continuously renewed gonocytes that reached the basement membrane would be enough to start spermatogenesis a puberty [11].

In the present study, lumen formation within the seminiferous cords occurred during the premature stage at 1.5 years of age. Researcher in this investigation [48] recorded that the horse puberty begins at 1-1.5 years of age, depending on the breed, and spermatogenesis is completed by 2 years of age. Similar observations in donkey were reported in this study.

The process of lumination seems to be governed by two phenomena. First, the dying germ cells always leave variably sized vacuoles in the center of the cords, which coalesce to form larger spaces that may represent the primary elements of lumination [44]. On the other hand, the high rate of division of germ cells in the premature stage and the concomitant access of these cells to the basal lamina may initiate lengthening of this membrane with subsequent increase in its external diameter, and to open the center of seminiferous cords that means lumination. 
Citation: Moustafa MNK, Sayed R, Zayed AE, Abd El -Hafeez (2015) Morphological and Morphometric Study of the Development of Seminiferous Epithelium of Donkey (Equus asinus) from Birth to Maturity. J Cytol Histol 6: 370. doi:10.4172/2157-7099.1000370

Page 7 of 8

In agreement with opinion of authors in study [19] the seminiferous epithelium of mature donkeys in the present investigation included eight cellular associations, which were considered as eight stages numbered from I to VIII. Stages V to VII have the same cellular composition, therefore they were considered as one stage.

The present findings indicate that the seminiferous epithelial cycle in mature donkeys has 8 stages are similar to result observed by different authors in different species: [49] in bull, [50] in water buffalo [51] in the ram, [20] in the donkey and mule, [10] in domestic cats, [52] in roe deer, [53] in the boar and [17] in the wild cats.

In agreement with observation in study [54] the Sertoli and germ cells, particularly spermatogonia, of the seminiferous epithelium of the mature donkeys in the present investigation were resting on the basement membrane at different stages of the seminiferous epithelial cycle, relying on its structural and hormonal support.

\section{Conclusion}

The tubular compartment of the donkey testis showed an increase in volume percentage on the expense of the interstitial tissue during the various postnatal ages due to increased tubular length convolutions. Such compartment increased from about $13 \%$ in neonates to about $78 \%$ in mature donkeys. The lumen formation within the seminiferous cords occurred during the premature stage at 1.5 years of age and spermatogenesis is completed by 2 years of age.

The supporting and germ cells were the main constituents of the seminiferous cords (tubules). The supporting cells decreased in number from neonatal through suckling to the premature and mature stages.

The germ cells showed a slight increase in number during the neonatal and suckling periods of the postnatal development. In addition, dividing germ cells were occasionally seen during postnatal development. Degenerating germ cells were sometimes seen in the different postnatal ages.

In premature donkeys, the seminiferous cords displayed more cellular components arranged in two or three layers of germ cells between the radially arranged supporting (Sertoli) cells. The germ cells could be distinguished as spermatogonia, primary spermatocyte, and in a few cords, secondary spermatocytes. In this stage of development, the first signs of lumination appeared. Spermatids at different transformation pictures were detected within the luminated seminiferous cords (tubules). On reaching the adult form, the seminiferous cords became more coiled and completely luminated (tubules). All kinds of germ cells as well as Sertoli cells are observed in the lining germinal epithelium representing the complete seminiferous cycle. Eight (I-VIII) stages (cellular associations) of the spermatogenic cycle were demonstrated in different sections of the seminiferous tubules. Each of these associations was made up from certain collection of germ cells in-between the radially arranged Sertoli cells.

\section{Acknowledgment}

The authors express great thanks to Dr. Karl Heinz Wrobel, Professor of Anatomy, Institute of Anatomy, Regensburg University for providing us with helpful advises and important resources and literature.

\section{References}

1. Borysenkoz M, Beringer $T$ (1988) Male reproductive system. In: functional histology, (3rd edn.) Little, Brown and Company, Boston, Toronto, London.

2. Siu MK, Cheng CY (2004) Dynamic cross-talk between cells and the extracellular matrix in the testis. Bioessays 26: 978-992.

3. Carmon JL, Green WW (1952) Histological study of the development of the testis of the ram. J Anim Sci 674-687.

4. Abdel-Raouf M (1960) The postnatal development of the reproductive organs in bulls with special reference to puberty (incluing growth of the hypophysis and the adrenals). Acta Endocrinol Suppl (Copenh) 34: 1-109.

5. Wrobel KH (2000) Prespermatogenesis and spermatogoniogenesis in the bovine testis. Anat Embryol (Berl) 202: 209-222.

6. Degen AA, Lee DG (1982) The male genital tract of the dromedary (onehumped) camel (Camelus dromedarius): gross and microscopic anatomy. Anat Histol Embryol 11: 267-282.

7. Baishya G, Ahmed S, Bhattacharya M (1987) Development of the testis in Assam goat (Capra hircus). Indian Vet J 24-28.

8. Orsi AM, Dias SM, Moreira JE, Camilli JA (1987) [Morphological development of the seminiferous epithelium of the pig at different ages (Sus scrofa of the Landrace strain)]. Anat Histol Embryol 16: 97-102.

9. Sánchez B, Pizarro M, García P, Flores JM (1993) Postnatal development of seminiferous tubules in the cat. J Reprod Fertil Suppl 47: 343-348.

10. França LR, Godinho CL (2003) Testis morphometry, seminiferous epithelium cycle length, and daily sperm production in domestic cats (Felis catus). Biol Reprod 68: 1554-1561.

11. Zayed AE, Moustafa MNK (1996) A histomorphological study on the testis of dog during postnatal life. Assiut Vet Med J 20: 31-46.

12. Myers M, Ebling FJ, Nwagwu M, Boulton R, Wadhwa K, et al. (2005) Atypical development of Sertoli cells and impairment of spermatogenesis in the hypogonadal (hpg) mouse. J Anat 207: 797-811.

13. Mackay S, Xie Q, Ullmann SL, Gilmore DP, Payne AP (2004) Postnatal development of the reproductive system in the grey short-tailed opossum, Monodelphis domestica. Anat Embryol (Berl) 208: 121-133.

14. Butler CM, Shaw G, Clark J, Renfree MB (2008) The functional development of Leydig cells in a marsupial. J Anat 212: 55-66.

15. Hayakawa D, Sasaki M, Suzuki M, Igot H, Kitamura N (2009) Classification of the seminiferous epithelial cycle in the sika deer (Cervus nippon). Mammal Study $34:$ 41-45.

16. Moura AA, Souzaa EAA, Erickson BH (2011) Early prepubertal testis criteria seminiferous epithelium and hormone concentrations as related to testicular development in beef bulls. Anim Reprod Sci 124: 39-47.

17. Balarini MK, de Paula TA, da Matta SL, Peixoto JV, Guião-Leite FL, et al (2012) Stages and duration of the cycle of the seminiferous epithelium in oncilla (Leopardus tigrinus, Schreber, 1775). Theriogenology 77: 873-880.

18. Saber AS (1994) Intertubular topography of the testis of donkey. Assiut Vet Med J 30: 39-50.

19. Nipken C, Wrobel KH (1997) A quantitative morphological study of age-related changes in the donkey testis in the period between puberty and senium. Andrologia 29: 149-161.

20. Neves ES, Chiarini-Garcia H, França LR (2002) Comparative testis morphometry and seminiferous epithelium cycle length in donkeys and mules. Biol Reprod 67: 247-255.

21. Caldeira BC, de Paula TAR, da Matta SLP, Balarini MK, Campos PKA (2010) Morphometry of testis and seminiferous tubules of the adult crab-eating fox (Cerdocyonthous, Linnaeus, 1766). Rev Ceres Viçosa 57: 569-575.

22. Muylle S, Simoens P, Lauwers H, Van Loon G (1999) Age determination in miniShetland ponies and donkeys. Zentralbl Veterinarmed A 46: 421-429.

23. Lin CC, Huang WJ, Chen KK (2009) Measurement of testicular volume in smaller testes: how accurate is the conventional orchidometer? J Androl 30: 685-689.

24. Wrobel KH, Moustafa MN (2000) On the innervation of the donkey testis. Ann Anat 182: 13-22

25. Drury RAB,Wallington EA, Cameron SR (1967) Carlton's Histological Technique. (4thedn). Oxford University Press, New York, Toronto.

26. Mollenhauer HH (1964) Plastic embedding mixtures for use in electron microscopy. Stain Technol 39: 111-114. 
Citation: Moustafa MNK, Sayed R, Zayed AE, Abd El -Hafeez (2015) Morphological and Morphometric Study of the Development of Seminiferous Epithelium of Donkey (Equus asinus) from Birth to Maturity. J Cytol Histol 6: 370. doi:10.4172/2157-7099.1000370

Page 8 of 8

27. Liu Z, Chang Q, Xu ZL, Zhang ZG (2009) Stereological measurement of rat's seminiferous tubule. Chin Med J (Engl) 122: 2643-2646.

28. Wrobel KH (1990) postnatal development of bovine Leydig cell population. Reprod Dom Anim 25: 51-60.

29. Gundersen HJ, Bendtsen TF, Korbo L, Marcussen N, Møller A, et al. (1988) Some new, simple and efficient stereological methods and their use in pathological research and diagnosis. APMIS 96: 379-94.

30. White D Jr, Berardinelli JG, Aune KE (2005) Age variation in gross and histological characteristics of the testis and epididymis in grizzly bear. Ursus 16:190-197.

31. Aydin F, Senturk N, Sahin B, Bek Y, Yuksel EP, et al. (2007) A practical method for the estimation of vitiligo surface area: a comparison between the poin counting and digital planimetry techniques. Eur J Dermatol 17: 30-32.

32. Osinubi AA, Noronha CC, Okanlawon AO (2005) Morphometric and stereological assessment of the effects of long-term administration of quinine on the morphology of rat testis. West Afr J Med 24: 200-205.

33. Morais DB, Barros MS, Paula TA, Freitas MB, Gomes ML, et al. (2014) Evaluation of the cell population of the seminiferous epithelium and spermatic indexes of the bat Sturnira lilium (Chiroptera: Phyllostomidae). PLoS One 9: e101759.

34. Wreford NG (1995) Theory and practice of stereological techniques applied to the estimation of cell number and nuclear volume in the testis. Microsc Res Tech 32: 423-436.

35. Berndtson WE (1977) Methods for quantifying mammalian spermatogenesis: a review. J Anim Sci 44: 818-833.

36. Clermont $Y$ (1972) Kinetics of spermatogenesis in mammals: seminiferous epithelium cycle and spermatogonial renewal. Physiol Rev 52: 198-236.

37. Lowseth LA, Gerlach RF, Gillett NA, Muggenburg BA (1990) Age-related changes in the prostate and testes of the beagle dog. Vet Pathol 27: 347-353.

38. Gofur MR, Khan MZI, Karim MR, Islam MN (2008) Histomrophology and histochemistry of testis of indigenous bull (Bos Inicus) of Bangladesh. Bangl. J Vet Med 6: 67-74.

39. Hadziselimovic F, Seguhi H (1974) Ultramikroskospische Untersuchungen an Tubulus Seminiferous bei Kindern von der Geburt bis zur Pubertät. II. Entwicklung und Morphologie der Sertolizellen. Verhandlungen der anatomischen Gesselschaft, Anatomischer Anzeiger 68: 140-161.

40. Petersen PM, Seierøe K, Pakkenberg B (2015) The total number of Leydig and
Sertoli cells in the testes of men across various age groups - a stereological study. J Anat 226: 175-179.

41. Sinowatz F, Amselgruber W (1986) Postnatal development of bovine Sertoli cells. Anat Embryol (Berl) 174: 413-423.

42. Curtis SK, Amann RP (1981) Testicular development and establishment of spermatogenesis in Holstein bulls. J Anim Sci 53: 1645-1657.

43. Chemes HE, Dym M, Raj HG (1979) Hormonal regulation of Sertoli cell differentiation. Biol Reprod 21: 251-262.

44. Santamarina E, Reece RP (1957) Normal Development of The Germinal Epithelium And Seminiferous Tubules In The Bull. Am J Vet Res 18: 261-278.

45. Ertl C, Wrobel KH (1992) Ultrastructure and morphometry of prepuberal postnatal germ cells development in the bovine testis. Reprod Dom Anim 27: 73-84.

46. Kawakami E, Tsutsui T, Ogasa A (1991) Histological observations of the reproductive organs of the male dog from birth to sexual maturity. J Vet Med Sci 53: 241-248.

47. Steger K, Wrobel KH (1996) Postnatal development of ovine seminiferous tubules: an electron microscopical and morphometric study. Ann Anat 178 201-213.

48. Clemmons AJ, Thompson DL Jr, Johnson L (1995) Local initiation of spermatogenesis in the horse. Biol Reprod 52: 1258-1267.

49. Wrobel KH, Schimmel M (1989) Morphology of the bovine Sertoli cell during the spermatogenetic cycle. Cell Tissue Res 257: 93-103.

50. Pawar HS, Wrobel KH (1991) Quantitative aspects of water buffalo (Bubalus bubalis) spermatogenesis. Arch Histol Cytol 54: 491-509.

51. Wrobel KH, Reichold J, Schimmel M (1995) Quantitative morphology of the ovine seminiferous epithelium. Ann Anat 177: 19-32.

52. Schön J, Göritz. F, Streich J, Blottner S (2004) Histological organization of roe deer testis throughout the seasonal cycle: variable and constant components of tubular and interstitial compartment. Anatomy and Embryology 208: 151-159.

53. Almeida FF, Leal MC, França LR (2006) Testis morphometry, duration of spermatogenesis, and spermatogenic efficiency in the wild boar (Sus scrofa scrofa). Biol Reprod 75: 792-799.

54. Siu MK, Cheng CY (2008) Extracellular matrix and its role in spermatogenesis. Adv Exp Med Biol 636: 74-91. 